\title{
A Study on the Efficacy of Shwasa Kasadi Gutika in the Management of Kasa
}

\author{
Research Article
}

\section{Akshay Patankar', Renu Rathi'*, Bharat Rathi ${ }^{3}$}

\author{
1. P.G Scholar, 2. Professor, Kaumarbhritya Department \\ 3. Professor, PG Department of Rasashastra and Bhaishajya Kalpana \\ Mahatma Gandhi Ayurved College, Hospital and Research Centre, Salod (H), Wardha.
}

\begin{abstract}
Kasa (Cough) is one of the most frequent symptoms in pediatric age group for which parents look for medical care. It indicates that even after advancements in current medical science, cough is not being effectively controlled in children. With the above background, the present trial was aimed to study the efficacy of herbal tablet named as Shwasa Kasadi gutika in the management of Kasa. The objectives of the study were to assess the efficacy of trial drug on Kasa and its subjective and objective parameters. The study was a single group, single centre, fixed dose, interventional study. The subjective parameters were as per the clinical features of Kasa. Their grading was done as per their intensity. School going age group was more likely to suffer from the cough and male children were more in the study. There was significant improvement in all subjective criteria where as significant changes were noted in adventitious sounds and total leukocyte count. However, as it was conducted in limited samples, further large sample multi-centre studies would be preferable. Developing pharmaceutical standards of the tablet would also be a newer area of research.
\end{abstract}

Key Words: Kasa, Shwasa Kasadi gutika, Cough in children, Ayurveda, Adventitious sounds.

\section{Introduction}

Kasa has been described under various sets in the classics of Ayurveda as independent disease, (1-2) symptom (3) and as complication (3). Numerous lakshana (sign and symptoms) of Kasa are explained in the classics of Ayurveda according to Dosha. In the pathogenesis of Kasa, vitiated Kapha blocks the free movement of Prana Vata in throat and chest (1) Kapha is the main offender in production of Kasa which is the leading Dosha in pediatric age group, (4) hence the incidence is more in this age group.

Pediatric age group is more prone because of anatomical and physiological individualities (hypertrophied lymphoid tissues (5) mucous hyper secretion (6) peculiarities of eustachian tube etc.)(7), immunological poor status(8) and social issues (appearing at school, improper food and eating habits (9) etc.). Recurrent cough is the common appearance of recurrent respiratory tract infections (RRTI) which is

\section{* Corresponding Author:}

\section{Renu Rathi}

Professor, PG Department of Kaumarbhritya.

Mahatma Gandhi Ayurved College, Hospital and Research Centre, Salod (H)

Datta Meghe Institute of Medical Sciences (deemed to be University), Sawangi(M), Wardha-442107

Email Id: rbr.226@gmail.com more parallel to the disease Kasa explained in Ayurveda classics.

Initial intervention is vital in case of Kasa as it is a probably Nidanarthakara Vyadhi (disease having affinity to create secondary diseases) to produce Kshaya (10) (a disease considered with severe leanness). It is noted that children suffering from RRTI show suggestively troubled growth and development with poor intellectual and social up-gradation.(11) Kasa may be observed as a common complaint of pediatric age without serious consequences, overlooking cough that may be the sole existing symptom of a primary respiratory disease can lead to late diagnosis and progression of a serious illness or chronic respiratory morbidity, such as bronchiectasis (12).

Shaman (Pacifying therapy) line of management that contains oral administration of medicine and pre-procedures of Panchkarma (5 purificatory procedures) is of prime importance as the administration is very easy as related to Shodhana (purificatary therapy) in children. Many herbal medicines are described in Ayurveda and their valuable effects in Kasa are yet to be explored. The effect of gutika containing equal quantities of Shunti, Nagarmotha, Haritaki (Herbal Drugs) and double of Jaggery is likely to be very effective in treating the signs and symptoms of Kasa. (13-14)

The present trial was aimed at studying the efficacy of herbal tablet named as Shwasa Kasadi gutika in the management of Kasa. The objectives of study were to assess the efficacy of Shwas Kasadi 
Gutika on Kasa frequency, Kantha Kandu (Throat itching), Peenasa (Nasal Discharge), Kapha Nishtivana (Sputum) and Adventitious Sound, TLC, DLC, ESR.

\section{Material and Methods}

It was a single group single center fixed dose interventional study. Before commencement of study, it was approved by Institutional Ethics committee (DMIMS (DU) /IEC/2017-2018/6371). The ShwasKasadi Gutika prepared and tested in analytical lab of Dattatray Rasashala of MGAC\&RC salod (H), Wardha. Total 34 patients accomplishing the inclusion criteria were enrolled from the OPD and IPD of Kaumarabhritya and also from specialized peripheral camps. Informed consent was taken from parents. The data was analyzed by using paired t test (Parametric), Wilcoxon sign rank (non- parametric) statistical tests.

\section{Inclusion Criteria}

- Subjects irrespective of gender, religion, socioeconomic status and between the age group of 4-15 years were being taken.

- Subjects having classical signs and symptoms of Kasa.

- Subjects of Kasa with chronicity of less than 15 days duration (Acute cases only).

\section{Exclusion Criteria}

- Subjects with complications of Kasa i.e, Fever $\left(>100^{\circ} \mathrm{F}\right)$, Chronic obstructive Bronchitis, Tuberculosis, Bronchiectasis, Lung abscess, Pulmonary edema resulting from Cardiac \& Renal disease, Pneumonia and Bronchiolitis.

- Subjects with other systemic disorders and metabolic diseases.

\section{Source of Drug}

For the present study, the poly herbal formulation was taken from Ayurveda classic (13-14) which contain the following ingredients.

\section{Table No1: Ingredients of Shwas-Kasadi Gutika:}

\begin{tabular}{|r|l|l|l|}
\hline $\begin{array}{l}\text { S1. } \\
\text { No. }\end{array}$ & Ingredients & Part used & $\begin{array}{l}\text { Quantity } \\
\text { per 900gm } \\
\text { of drug }\end{array}$ \\
\hline 1 & $\begin{array}{l}\text { Haritaki Terminalia } \\
\text { chebula (Retz.) }\end{array}$ & $\begin{array}{l}\text { Phala } \\
\text { (Fruit) }\end{array}$ & $100 \mathrm{gm}$ \\
\hline 2 & $\begin{array}{l}\text { Nagara Zingiber } \\
\text { officinale (Rosc.) }\end{array}$ & $\begin{array}{l}\text { Kanda } \\
\text { (Rhizome) }\end{array}$ & $100 \mathrm{gm}$ \\
\hline 3 & $\begin{array}{l}\text { Musta } \\
\text { Cyperus rotundus } \\
\text { (Linn.) }\end{array}$ & $\begin{array}{l}\text { Stoloniferous } \\
\text { roots }\end{array}$ & $100 \mathrm{gm}$ \\
\hline 4 & $\begin{array}{l}\text { Jaggery } \\
\text { Sa c c h a } r \text { u m } \\
\text { officinaram (Linn.) }\end{array}$ & Jaggery & $600 \mathrm{gm}$ \\
\hline
\end{tabular}

Dosage - $100 \mathrm{mg} / \mathrm{kg} / \mathrm{day}$,

Mode of administration - Oral (licking)

\section{Method of study}

After taking the informed consent from the parents /guardian, 34 subjects were enrolled as per the inclusion criteria. The trial drug was administered for a period of 7 days during which assessment of both subjective and objective parameters and other observations were recorded on $0^{\text {th }}, 3^{\text {rd }}$ and $7^{\text {th }}$ day in a specially prepared research proforma other than hematological parameters which were performed before and after trial. Follow up was for a period of 14 days post trial.

Withdrawal criteria was fixed as any aggravation of symptoms or occurrence of any other clinical condition during treatment for which participants would be withdrawn from study and suitable alternative would be provided free of cost till the children were symptom free.

\section{Criteria for Assessment}

Assessment of the clinical trial was done based upon the changes in both subjective (Numerical gradation as per severity) [Baghail book] and objective parameters.

Initial assessment was done before the study, followed by assessment of only subjective parameters on 4th day of the study. Final assessment was done after the course of the trial i.e. on 7th day and follow-up at 15 days after completion of treatment. Hematological investigations were done only before and after the clinical trial.

Table No 2: Subjective and Objective parameter

\begin{tabular}{|c|c|}
\hline $\begin{array}{l}\text { Subjective } \\
\text { Parameters }\end{array}$ & $\begin{array}{l}\text { O b j e c t i v e } \\
\text { Parameters: }\end{array}$ \\
\hline $\begin{array}{l}\text { - Kasa-nature in general } \\
\text { with overall discomfort } \\
\text { - Kasa (Frequency) } \\
\text { - Kanthkandu (itching } \\
\text { inside throat) } \\
\text { - Peenas ( N a s a } 1 \\
\text { Discharge) } \\
\text { - Kapha Nistivanam } \\
\text { (Expectoration) }\end{array}$ & $\begin{array}{l}\text { - Adventitious } \\
\text { sounds as they are } \\
\text { signs for type, } \\
\text { severity \& } \\
\text { frequency to be } \\
\text { checked by doctor } \\
\text { - TLC, DLC } \\
\text { - ESR }\end{array}$ \\
\hline
\end{tabular}

The obtained data was analyzed statistically with the help of Wilcoxon Signed Rank Test and Paired $t$ test. P value of $<0.05$ was considered as statistically significant and $\mathrm{p}$ value $<0.01$ and $<0.001$ were considered as highly significant. Level of significance was noted and interpreted accordingly. Overall assessment of the study was done by calculating the mean of parameters.

\section{Observations and result}

Total 34 subjects were enrolled in the study among which 2 had left against medical advice due to personal reasons. 2 children reported with high grade fever soon after enrollment in the trial hence they were withdrawn from study and suitable alternative was provided free of cost till they were symptom free.

Maximum number of children i.e. 20 belonged to the age group of $8-10$ years and there were 20 male 
and 14 female children in this study. Among 34 participants-30 Hindu and 4 Buddhist were enrolled. Maximum numbers of children were from middle class followed by lower class and no children were from upper class family.15 children had average personal hygiene whereas 15 had poor. Maximum numbers of children were having history of gradual mode of onset, intermittent time of occurrence, irregular periodicity with expectoration of white sputum.

Table No 3: Effect of Shwasa Kasadi Gutika in Kasa nature

\begin{tabular}{|l|c|c|c|c|c|c|}
\hline Day & Mean & $\mathbf{N}$ & SD & SE & Mean Difference & z-value \\
\hline $\begin{array}{l}\text { 0 day-before } \\
\text { treatment }\end{array}$ & 2.43 & 30 & 0.50 & 0.09 & - & - \\
\hline 3rd day & 2.10 & 30 & 0.30 & 0.05 & $\begin{array}{c}0.33 \pm 0.47 \\
(13.58 \%)\end{array}$ & $\begin{array}{c}3.16 \\
\mathrm{p}=0.002, * *\end{array}$ \\
\hline 7th day & 1.33 & 30 & 0.47 & 0.08 & $\begin{array}{c}1.10 \pm 0.30 \\
(45.26 \%)\end{array}$ & $\begin{array}{c}5.26 \\
\mathrm{p}=0.0001, * * * \\
\text { (t) }\end{array}$ \\
\hline 22nd day & 1.03 & 30 & 0.18 & 0.03 & $1.40 \pm 0.56$ & $\begin{array}{l}4.85 \\
\mathrm{p}=0.0001, * * *\end{array}$ \\
\hline
\end{tabular}

*Insignificant, $* *$ Significant, $* * *$ Highly Significant

Table No 4 - Effect of Shwasa Kasadi Gutika in Kasa (Frequency)

\begin{tabular}{|c|c|c|c|c|c|c|}
\hline Day & Mean & $\mathbf{N}$ & SD & $\mathbf{S E}$ & $\begin{array}{c}\text { Mean } \\
\text { Difference }\end{array}$ & z-value \\
\hline $\begin{array}{l}0 \text { day-before } \\
\text { treatment }\end{array}$ & 3.16 & 30 & 0.46 & 0.08 & - & - \\
\hline $3 r d$ day & 2.06 & 30 & 0.25 & 0.04 & $\begin{array}{l}1.10 \pm 0.40 \\
(34.81 \%)\end{array}$ & $\begin{array}{c}4.69 \\
\mathrm{p}=0.001, *\end{array}$ \\
\hline 7th day & 1.33 & 30 & 0.47 & 0.08 & $\begin{array}{l}1.83 \pm 0.37 \\
(57.91 \%)\end{array}$ & $\begin{array}{c}10.38 \\
\mathrm{p}=0.0001, * * *\end{array}$ \\
\hline 22nd day & 1.03 & 30 & 0.18 & 0.03 & $2.13 \pm 0.50$ & $\begin{array}{c}10.38 \\
\mathrm{p}=0.0001, * * *\end{array}$ \\
\hline
\end{tabular}

Table No 5: Effect of Shwasa Kasadi Gutika in Kantha Kandu

\begin{tabular}{|l|l|l|l|l|l|l|}
\hline Day & Mean & N & SD & SE & $\begin{array}{l}\text { Mean } \\
\text { Difference }\end{array}$ & z-value \\
\hline $\begin{array}{l}\text { 0 day-before } \\
\text { treatment }\end{array}$ & 2.07 & 14 & 0.26 & 0.07 & - & - \\
\hline 3rd day & 1.64 & 14 & 0.49 & 0.13 & $\begin{array}{l}0.42 \pm 0.51 \\
(20.77 \%)\end{array}$ & $\begin{array}{l}3.12 \\
\mathrm{p}=0.008, * *\end{array}$ \\
\hline 7th day & 1.07 & 14 & 0.26 & 0.07 & $\begin{array}{l}1.00 \pm 0.39 \\
(93.45 \%)\end{array}$ & $\begin{array}{l}9.53 \\
\mathrm{p}=0.0001, * * *\end{array}$ \\
\hline 22nd day & 1.00 & 14 & 0.00 & 0.00 & $1.07 \pm 0.26$ & $\begin{array}{l}15.00 \\
\mathrm{p}=0.0001, * * *\end{array}$ \\
\hline
\end{tabular}

Table No 6: Effect of Shwasa Kasadi Gutika Peenasa (Nasal Discharge)

\begin{tabular}{|l|c|c|c|c|c|c|}
\hline Day & Mean & N & SD & SE & $\begin{array}{c}\text { Mean } \\
\text { Difference }\end{array}$ & z-value \\
\hline $\begin{array}{l}\text { 0 day-before } \\
\text { treatment }\end{array}$ & 2.27 & 22 & 0.45 & 0.09 & - & - \\
\hline 3rd day & 2.04 & 22 & 0.48 & 0.10 & $\begin{array}{c}0.22 \pm 0.42 \\
(10.13 \%)\end{array}$ & $\begin{array}{c}2.48 \\
\mathrm{p}=0.021, * *\end{array}$ \\
\hline 7th day & 1.09 & 22 & 0.29 & 0.06 & $\begin{array}{c}1.18 \pm 0.39 \\
(51.98 \%)\end{array}$ & $\mathrm{p}=0.0001,{ }^{* * *}$ \\
\hline 22nd day & 1.13 & 22 & 0.35 & 0.07 & $1.13 \pm 0.35$ & $\begin{array}{c}15.17 \\
\mathrm{p}=0.0001, * * *\end{array}$ \\
\hline
\end{tabular}


Assessment of objective Criteria

Table No 7: Effect of Shwasa Kasadi Gutika on Adventitious Sound

\begin{tabular}{|c|c|c|c|c|c|c|}
\hline $\begin{array}{c}\text { Day } \\
\text { 0 day-before } \\
\text { treatment }\end{array}$ & Mean & N & SD & SE & Mean Difference & z-value \\
\hline 3rd day & 1.16 & 12 & 0.38 & 0.11 & - & - \\
\hline 7th day & 1.00 & 12 & 0.52 & 0.15 & $\begin{array}{c}0.66 \pm 0.49 \\
(30.55 \%)\end{array}$ & $\begin{array}{c}4.69 \\
\mathrm{p}=0.001, * *\end{array}$ \\
\hline 22nd day & 1.00 & 12 & 0.00 & 0.00 & $\begin{array}{c}1.16 \pm 0.38 \\
(53.70 \%)\end{array}$ & $\begin{array}{c}\text { p }=0.0001, * * * \\
10.38\end{array}$ \\
\hline
\end{tabular}

Hematological Parameters:- Total Leukocyte count shows significant result $(\mathrm{p}=0.011)$ all other hematological parameters shows not significant result

Table no. 8 showing details on objective criteria- Hematological parameters

\begin{tabular}{|c|c|c|c|c|c|c|}
\hline $\begin{array}{c}\text { Parameter } \\
\text { Pre\& Post } \mathrm{t} / \mathrm{t}\end{array}$ & Mean & $\mathbf{N}$ & SD & SE & $\begin{array}{c}\text { Mean } \\
\text { Difference }\end{array}$ & t-value \\
\hline $\mathrm{Hb}$ & $\begin{array}{l}11.03 \\
10.98\end{array}$ & 30 & $\begin{array}{l}1.63 \\
1.56\end{array}$ & $\begin{array}{l}0.29 \\
0.28\end{array}$ & $\begin{array}{c}0.05 \pm 0.36 \\
(0.45 \%)\end{array}$ & $\begin{array}{c}0.79 \\
\mathrm{p}=0.43\end{array}$ \\
\hline Leukocyte & $\begin{array}{l}8120 \\
7316\end{array}$ & 30 & $\begin{array}{l}2400 \\
2230\end{array}$ & $\begin{array}{l}438.31 \\
407.23\end{array}$ & $\begin{array}{c}803.333 \pm \\
1619.90 \\
(9.89 \%)\end{array}$ & $\begin{array}{c}2.71 \\
\mathrm{p}=0.011 * *\end{array}$ \\
\hline Neutrophil & $\begin{array}{l}56.46 \\
56.20\end{array}$ & 30 & $\begin{array}{l}10.84 \\
12.05\end{array}$ & $\begin{array}{l}1.97 \\
2.20\end{array}$ & $\begin{array}{c}0.26 \pm 7.55 \\
(0.46 \%)\end{array}$ & $\begin{array}{c}0.19 \\
\mathrm{p}=0.84, *\end{array}$ \\
\hline Lymphocyte & $\begin{array}{l}35.40 \\
38.13\end{array}$ & 30 & $\begin{array}{c}12.90 \\
9.81\end{array}$ & $\begin{array}{l}2.35 \\
1.79\end{array}$ & $\begin{array}{c}2.73 \pm 8.50 \\
(7.71 \%)\end{array}$ & $\begin{array}{c}1.75 \\
\mathrm{p}=0.089, *\end{array}$ \\
\hline Eosinophil & $\begin{array}{l}2.26 \\
2.30\end{array}$ & 30 & $\begin{array}{l}1.14 \\
1.02\end{array}$ & $\begin{array}{l}0.20 \\
0.18\end{array}$ & $\begin{array}{c}0.03 \pm 1.09 \\
(1.76 \%)\end{array}$ & $\begin{array}{c}6.16 \\
p=0.86, *\end{array}$ \\
\hline Monocyte & $\begin{array}{l}3.70 \\
4.26\end{array}$ & 30 & $\begin{array}{l}2.13 \\
2.51\end{array}$ & $\begin{array}{l}0.38 \\
0.45\end{array}$ & $\begin{array}{c}0.56 \pm 2.14 \\
(15.13 \%)\end{array}$ & $\begin{array}{c}1.44 \\
\mathrm{p}=0.15, *\end{array}$ \\
\hline ESR & $\begin{array}{l}25.73 \\
21.66\end{array}$ & 30 & $\begin{array}{l}16.51 \\
16.71\end{array}$ & $\begin{array}{l}3.01 \\
3.05\end{array}$ & $\begin{array}{c}4.06 \pm 11.95 \\
(15.81 \%)\end{array}$ & 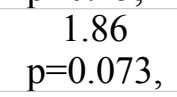 \\
\hline
\end{tabular}

Table No 9: Over All Result on Assessment Criteria ( $\mathrm{Z}$ test)

\begin{tabular}{|c|c|c|c|c|c|}
\hline SL No & $\begin{array}{l}\text { Assessment } \\
\text { Criteria }\end{array}$ & Fully Cured & Partially Relief & No Effect & $\begin{array}{c}\text { Overall } \\
\text { Improvement in } \\
\%\end{array}$ \\
\hline 1 & Kasa Nature & $66.66 \%$ & $33.33 \%$ & $0 \%$ & $45.26 \%$ \\
\hline 2 & $\begin{array}{c}\text { Kasa } \\
\text { (Frequency) }\end{array}$ & $66.66 \%$ & $33.33 \%$ & $0 \%$ & $57.91 \%$ \\
\hline 3 & Kantha Kandu & $92.85 \%$ & $0 \%$ & $7.14 \%$ & $93.45 \%$ \\
\hline 4 & $\begin{array}{l}\text { Peenasa(Nasal } \\
\text { Discharge) }\end{array}$ & $90.90 \%$ & $9.09 \%$ & $0 \%$ & $51.98 \%$ \\
\hline 5 & $\begin{array}{c}\text { Kapha } \\
\text { Nistivanam(Spu } \\
\text { tum) }\end{array}$ & $91.30 \%$ & $8.69 \%$ & $0 \%$ & $52.71 \%$ \\
\hline \multirow[t]{2}{*}{6} & $\begin{array}{l}\text { Adventitious } \\
\text { Sounds }\end{array}$ & $100 \%$ & $0 \%$ & $0 \%$ & $53.70 \%$ \\
\hline & Total Result & & $14.07 \%$ & $1.09 \%$ & $59.16 \%$ \\
\hline
\end{tabular}

The assessment shows that all the subjective parameters have a highly significant association with the $\mathrm{p}$ value obtained. In objective criteria, in Adventitious Sound shows highly significant result Lymphocyte counts which showed significant results, all the others have an insignificant association with the $\mathrm{p}$ value obtained. Overall Improvement seen in Kasa Assessment criteria is $59.16 \%$ which shows Moderate improvement as Improvement is in between $50 \%$ to
$75 \%$. Comparing the overall results, the percentage of fully cured children is far more as compared to partial relief children. Maximum children enrolled in the study had shown mild sign and symptoms only and very few were affected with moderate sign symptoms so after treatment there is moderate overall improvement i.e. $59.16 \%$ was found in final result. The individual and overall effect of therapy was tested for statistical significance by using Wilcoxan sign rank test and 
Student's ' $\mathrm{t}$ ' test including mean \%. Shwasa Kasadi Gutika provided relief in all symptoms of Kasa irrespective of Doshika involvement. The total remission was statistically highly significant (i.e. $\mathrm{P}<0.001$ ).

\section{Discussion}

In the present study, school going age group was more likely to suffer from the cough which might be due to exposure to external environment and contact with infected group of children. Male children were more in the study since they have smaller air ways for a given lung size, which is independently inherited in addition to the fact that boys have a higher incidences of respiratory infections during childhood(15). With respect to religion, it was observed that maximum number of children belonged to Hindu community, followed by Buddhist. This may be due to the geographical distribution of the particular set in the place of study. Prevalence of Kasa belonging to lower middle and lower class family can be considered as a reasonable finding due to the surrounding in which they live, poor personal as well as social hygiene and negligence towards health which provokes respiratory infections. The same was observed in the study. All participants were accurately immunized up to their age by routine vaccines, suggesting the lack of relation between the disease and immunization. As vaccines only stimulate specific immunity to disease specific (16) and they are not directly associated in preventing routine infections.

Regarding nature of Kasa (Cough), 46.66\% subjects revealed history of gradual onset of Kasa while sudden onset was found in $43.33 \%$ in whom specific allergic substances had a key role. 10\% children had episodic mode of onset which was due to environmental factors and seasonal changes. Maximum number of children presented with productive cough which is a classical sign of Kapha dosha dominance. Wet cough specifies an underlying reason of mucous hyper secretion or impaired muco-ciliary clearance, whereas a dry cough specifies basic reason of airway inflammation or a non-airway cause (17). Thus, in the present study dominance of Kapha dosha causing productive cough might be due to the above cited fact. Children with intermittent cough were in maximum number. It is due to reflex mechanism of body to expectorate the secretions in the air way. Irregular periodicity of cough was seen in maximum children. It is during the change of season which is called as Rutusandhi kala (duration between two seasons) in Ayurveda wherein observing Rutucharya (Seasonal Regimen) is said to be very vital. Children generally do not follow these guidelines and thus, suffer from various seasonal diseases. $63.33 \%$ participants had white color of sputum which is due to kapha dominance and it is a classical sign of Kapha dosha dominant Kasa.

\section{Discussion on Kasa nature and frequency}

The trial drug with its vata Kaphahara properties might have modified the disease-causing properties of Kapha and reduced obstruction of channel of the body also facilitating normal movements of Vata which has reduced Kasa Vega/frequency. Haritaki is having Immune modulatory activity (18) and Antitussive action of Shunthi (19) Haritaki (20) is helpful in treating Kasa.

\section{Kantha Kandu}

Pharmacological Activity of drug Swasa Kasadi Gutika was proved as Anti-bacterial activity (21) Antiviral activity (22) of Haritaki and it shows direct effect on chronic cough and sore throat (23), Z. officinale has been reported to exhibit antibacterial properties and exerts anti-inflammatory and relaxant effects on airway lumen(24), Antimicrobial (25), Antibacterial (26), AntiInflammatory (27), Tranquilizing (28) effect of Musta collectively shows significant effects in Kantha kandu.

\section{Peenasa (Nasal Discharge)}

Anti-viral, Anti-Bacterial effect of all drugs Haritaki is having immune-modulatory activity(18)Anti-allergic activity of Haritaki (29) and Tranquilizing activity(28) of Musta which helps in sedating the child which is useful in case of peensa thus, all collective effect of trial drug has shown significant effect on Peenasa.

\section{Kapha Nistivanam (Sputum)}

All the drugs are having Vata-kaphahara properties and Ushnaguna (Hot potency) (30) which help in expectoration by resolving reduced obstruction of channel because of this drug- Swasa Kasadi Gutika collectively showed significant improvement.

\section{Adventitious Sounds}

Adventitious sounds were reduced because of ushanaguna and Vatkaphahara property of drugs (30) which resolve the strotorodha and maintain the natural flow of Vata in the chest region. Antibacterial (21), Anti-viral (22) Anti-microbial $(25,31)$ activity of drugs helped to reduce adventitious sound like crepitation and rhonchi.

\section{Hematological parameters}

Total lymphocyte counts also showed significant results. All the other blood investigations have an insignificant association with the $\mathrm{p}$ value obtained. DLC and ESR value had not shown significant result because of values of these criteria were not much deranged before the treatment so found minimal changes in the value.

\section{Probable Mode of Action of Drug- Shwasa Kasadi Gutika}

The drug had Madhura-Kashaya and katu Rasa (sweet-astringent taste). Jaggery was the ingredient for the sweet taste and as per Ayurveda considers jaggery to be beneficial in treating throat and lung infections(32,33), Haritaki is having abundant tannins which exhibit surface action on the pharyngo-laryngeal mucosa and modulate them to decrease exudation (34). Also Haritaki is having Antibacterial (21), Antiviral 
(22), Anti-inflammatory (35), Immuno-modulatory activity (18), Anti-allergic (29) activities and Antitussive activities (20), used in chronic cough and sore throat(23). Shunthi is having AntiInflammatory(36) Antitussive Effects $(37,38)$ Immunomodulatory Effects(39) with Antimicrobial Activities(31). Musta is having Anti-Inflammatory Activity (27), Antipyretic activity (40), Analgesic activity (41), Antimicrobial activity(25) Antibacterial Activity (26), Anti-Inflammatory (27) and also Tranquilizing activity (28).

In modern viewpoint the drugs with pungent taste and hot potency such as Nagara and Musta acts as the local counter irritants and block the efferent fibers of vagus which transmit the cough stimuli to the cough center act as a antitussives(42) It also maintain digestive fire which is the main reason of any disease to occur or recur again $(43,44,45)$. In follow-up, found good results.

\section{Conclusion}

The present study revealed the efficacy of the poly herbal tablet 'Shvasa Kasadi Gutika' as a safe and effective preparation in pediatric cough without any reported adverse reaction. The drug was well accepted by the children with respect to palatability. Main dosha involved in the pathology of Kasa in the children was Kapha. In this study, Shvasa Kasadi Gutika showed highly significant results in all the subjective parameters of Kasa and in objective parameters in TLC and adventitious sounds.

This study was hospital based so limited population was covered. The study should be conducted on large sample size so that large number of patients could benefit with the trial drug.

\section{Acknowledgement}

The authors would like to thank the Institution for providing the facility for this research work.

\section{References}

1. Agnivesha. Charaka Samhita Chakrapani commentary. Chikitsasthana 18. Yadavji Trikamaji Acharya, editor. Varanasi;Chaukhambha Sanskrit Prakashana; 2009; p 454-478.

2. Sushruta. Sushruta Samhita, Dalhana commentary. Nibandha samgraha, Uttaratantra 52. PriyaVrat Sharma editor. Varanasi;Chaukhambha Sanskrit Sansthan; reprint 2012; p.432-440

3. Harita. Harita Samhita. Tritiyasthana 12, JayminiPandey editor. Varanasi; Chaukhambha VisvabharatiPrakashana; 2010; p. 326-332

4. Vagbhata. Astanga Hridayam, Sutrasthanam (1/7). Brahman and Tripathi editor. Delhi; Chaukhambha Sanskrit Prakashana; 2009; p. 9

5. Hibbert J. Tonsils and Adenoids. In: Kerr AG, editor. Scott. Brown's Otolaryngology.5th ed. Vol. 6. London; Butterworths and Co. Ltd; 1987; p. 368 83

6. Kvaerner KJ, Nafstad P, Jaakkola JJ. Upper respiratory morbidity in preschool children: a cross- sectional study. Arch Otolaryngol Head Neck Surg.; 2000.126.1201-6. [PubMed]

7. Maw AR. Otitis media with effusion. In: Kerr AG, editor. Scott Brown's Otolaryngology.5th ed. Vol. 6. London: Butterworths and Co. Ltd; 1987; p. 57-76

8. Kay AB. Allergy and allergic diseases. N Engl J Med. 2001; 344:30. 109 [PubMed]

9. Hill DJ, Hosking CS, Heine RG. Clinical spectrum of food allergy in children in Australia and SouthEast Asia; identification and targets for treatment. Ann Med. 1999; 31:272-278 [PubMed]

10. Agnivesha. Charaka Samhita. Chakrapani commentary. Nidanasthana (8/19). Brahman and Tripathi editor. Varanasi; Chaukhambha Surbharti Prakashan; 2009; p. 651

11. Ghai OP. Normal growth and its disorders. In: Ghai OP, Vinod KP, Arvinb B, editors. Ghai Essential Pediatrics 7th ed. New Delhi; CBS Publishers and Distributors; 2009; p.2

12. Barr RL, McCrystal DJ, Perry CF, Chang AB. A rare cause of specific cough in a child: The importance of following-up children with chronic cough. Cough. 2005; 1:8. [PMC free article] [PubMed]

13. Sharngadhara. Sarngadhar-Samhita. MadyamaKhand (7/16). K.R. Srikantha Murthy editor. Varanasi; Chaukhamba orientalia; 2012; p. 103

14. Chakradatta. Kasa Chikitsa (11/31). PriyaVrat Sharma editor. Delhi; Chaukhambha Orientalia; 2007; p.139

15. A Parthasarathy. PSN Menon, MKC Nair. IAP Textbook of Pediatrics. 2nd ed. New Delhi, India; Jaypee Brothers Medical Publishers, Ltd; 2002; p. 400

16. Singhal T, Abdekar YK, Agarwal RK. IAP Guide Book on Immunization. New Delhi; Jaypee Brothers Medical Publishers (P) LTD; 2009; p. 5

17. Shields M.D., Doherty G.M. Chronic cough in children Paediatr Respir Rev. 2013; 14;100-105

18. Aher V and Wahi A. Immunomodulatory Activity of Alcohol Extract of Terminalia chebula Retz Combretaceae. Tropical Journal of Pharmaceutical Research. October 2011; 10; 567-575

19. Suekawa M, Ishige A, Yuasa K, Sudo K, Aburada $\mathrm{M}$ and Hosoya E. Pharmacological studies on ginger. I. Pharmacological actions of pungent constitutents, (6)-gingerol and (6)-shogaol. J Pharmacobiodyn. 1984;7; 836-848

20. Nadkarni, K.M., Indian Material Medica. Bombay; Popular Prakashan Pvt. Ltd.; 1976; p.1202-1211

21. Kannan P, Ramadevi S, Hopper W. Anti-bacterial activity of Terminaliachebula fruit extract. African J Microbiol Res.2009;3;180-84

22. Mekkaway S, Meselhy M, Kusumoto I, Kadota S, Hattori M, Namba T. Inhibitory effects of Egyptian folk medicines on human immunodeficiency virus (HIV) reverse transcriptase. Chemical \& Pharmaceutical Bulletin; 1995;43;641-48

23. Dastur, J.F. Medicinal Plants of India and Pakistan. D.B. Bombay; Taraporevala Sons and Co. Pvt. Ltd.;1962; p.162-163. 
24. Akoachere JF, Ndip RN, Chenwi EB, Ndip LM, Njock TE, Anong DN, et al. Antibacterial effect of Zingiberofficinale and Garcinia kola on respiratory tract pathogens. East Afr Med J. 2002;79;588-592

25. Zeidabdul-Majid Nima, Majid Sakhi Jabier ,Raghidah Ismaeel Wagi, Huda Abd AlKareem Hussain. Extraction, Identification and Antibacterial activity of Cyperus oil from Iraqi $\mathrm{C}$ rotundus,. Eng. \& Technology. 2008;26;10-18.

26. Chandratre R. S., Chandarana S, Mengi S. A. Effect of Aqueous Extract of Cyperusrotundus on Hyper lipidaemia in Rat Model. International Journal of Pharmaceutical \& Biological Archives. 2012; 3;598-600

27. Singh N and Gilca M. Herbal Medicine - Science embraces tradition - A new insight into the ancient Ayurveda. Germany; Lambert Academic Publishing; 2010;139-148

28. Singh N, Kulshrestha VK, Gupta MB and Bhargava K P. A pharmacological study of Cyperusrotundus. Indian J Med. Res.1970;58;103-109

29. Pratibha N, Saxena VS, Amit A, D'Souza P, Bagchi M, Bagchi D. Anti-inflammatory activities of Aller-7, a novel polyherbal formulation for allergic rhinitis. Int J Tissue React. 2004;26;43-51 [PubMed] [Google Scholar]

30. Sastry JLN. Dravyaguna Vijnana 2nd ed.Vol.2. Varanasi; Chaukhambha Orientalia; 2005; p.209-214

31. Sundaram, M.S., Sivakumar, T., Balamurugan, G. Anti-inflammatory effect of Cyperusrotundus Linn. Leaves on acute and subacute inflammation in experimental rat models Biomedicine. 2008;28; p.302-304

32. Rathi Renu, A Clinical study on Kasahar kwath and sadya Sneha in younger children of URTI. Journal of Indian system of Medicine. 2013;1;1;25-30

33. Rajesh CK. Ayurvedic Review On Guda (Jaggery). Ayurpharm Int J Ayur AlliSci. 2016;5;68 - 76

34. Rakesh K. Johri, Neelima Thusu, Annu Khajuria, Usha Zutshi. Piperine-mediated changes in thepermeability of rat intestinal epithelial cells. The status of $\gamma$-glutamy ltranspeptidase activity. Uptake of amino acids and lipid peroxidation, Biochemical Pharmacology.1992;43;1401-1407

35. Nair V, Singh S, Gupta YK. Anti-arthritic and disease modifying activity of Terminaliachebula
Retz.in experimental models. J Pharm Pharmacol.2010;62;1801-1806

36. Chrubasik S, Pittler $\mathrm{MH}$ and BD. Zingiberis rhizoma: a comprehensive review on the ginger effect and efficacy profiles. Phytomedicine.2005;12; 684-701

37. Suekawa M, Ishige A, Yuasa K, Sudo K, Aburada $M$ and Hosoya E. Pharmacological studies on ginger. I. Pharmacological actions of pungent constitutents, (6)-gingerol and (6)-shogaol. J Pharmacobiodyn.1984;7; $836-848$

38. Rathi B, Rathi R \& Khobragade P. Relevance of Ayurveda Antiviral herbal wisdom from the perspective of current researches. Int. J.Res. Pharm. Sci.,2020,11(1)Spl:175-183

39. Miri P, Bae J and Lee DS. Antibacterial activity of [10]-gingeroland [12]-gingerol isolated from ginger rhizome against periodontal bacteria. Phytothery Res. 2008; 22;1446-1449

40. Gupta MB, Palit TK, Singh N, Bhargava KP. Pharmacological studies to isolate the active constituents from Cyperusrotundus possessing antiinflammatory, anti-pyretic and analgesic activities. Indian Journal of Medical Research.1971;59;76-82

41. Birdar S, Kangralkar V A, Mandavkar Y, Thakur M and Chougule N. Anti-inflammatory, anti-arthritic, analgesic anticonvulsant activity of Cyprus essential oils, Int J Pharm Parmaceut Sci.2010;2;112-115

42. Tripathi KD. Drugs Acting on Skin and Mucous Membrane; In Essentials of Medical Pharmacology. 5th ed. New Delhi; Jaypee Brothers Medical Publishers; 2004, p. 795

43. Rathi R, Rathi B, Sharma S, Rajput DS. Management of childhood Protein Energy Malnutrition through Ayurvedic interventions. Joinsysmed.2017,15;3;196-202

44. Rathi R, Rathi B. COVID 19 Pandemic and Preventive Footsteps. Int $\mathrm{J}$ Ayu Pharm Chem. 2020;12;3;100-106

45. Baghel MS \& Rajagopala S., Developing guidelines for clinical research methodology in Ayurveda, Institute for Post Graduate Teaching and Research in Ayurveda, Gujarat Ayurveda University(GAU), Jamnagar India, 2009, p 41 